\title{
Neither plague nor malaria, but dysentery as a cause of death for St. Louis
}

\author{
Philippe Charlier ${ }^{1,2}$
}

Accepted: 15 December 2015/Published online: 12 January 2016

(C) Springer Science+Business Media New York 2016

As stated by Faure, we too have serious doubts about the fact that true plague (i.e., infection by Yersinia pestis) did play a direct role in the mechanism and cause of death of Saint-Louis in 1270. The absence of any plague buboes in all descriptions of the king's body is the first reason. Secondly, according to many scholars, this epidemic was clearly absent from northern Africa at this period [1].

Based on the medical description of Saint-Louis, Faure asked for complementary analyses on the mummified intestines, for any positivity for malaria testing. This would serve no purpose as malaria did not cause the final symptomatology of the King.

Diarrhea attributable to malaria is thought to be much more common among children and non-immune adults with hyperparasitemia [2], which does not fit with the case of Saint-Louis. Moreover, it has to be said that the identification of Plasmodium within the remains of a dead body, even of archeological origin, does not imply a death related to malaria: Plasmodium vivax was identified within the putrefaction fluid deposits [3] of the French queen Charlotte de Savoie (who died in 1483 at the age of 42 years, of a respiratory disease) and the official King's mistress Agnès Sorel (who died in 1450 at the age of
28 years, of acute mercury poisoning) independently from their cause of death [4].

At this moment, we are still testing samples of SaintLouis' embalmed intestines for viruses, bacteria, and parasites that could be compatible with the dysenteric syndrome presented by the King and his court at the moment of the 8th Crusade. Shigella, E. Coli, and amebiasis infection would fit best with the historical descriptions by the chronicler of this episode, Jean of Joinville [5].

\section{References}

1. Mollaret HH, Brossollet J. On the death of Saint-Louis. Presse Med. 1966;74:2913-6.

2. Prasad RN, Virk KJ. Malaria as a cause of diarrhea. A review. PNG Med J. 1993;36:337-41.

3. Charlier P, Georges P, Bouchet F, et al. The microscopic (optical and SEM) examination of putrefaction fluid deposits (PFD). Potential interest in forensic anthropology. Virchows Arch. 2008;453:377-86.

4. Charlier P, Brun L. An endemic medieval parasitosis. Ann Pathol. 2010;30:160-2.

5. Pfeiffer ML, DuPont HL, Ochoa TJ. The patient presenting with acute dysentery. A systematic review. J Infect. 2012;64:374-86.

Philippe Charlier

philippe.charlier@uvsq.fr

1 Section of Medical and Forensic Anthropology (UVSQ/EA 4569 Paris-Descartes), 2 avenue de la source de la Bièvre, 78180 Montigny-le-Bretonneux, France

2 CASH, Nanterre, France 